IJBPA

39,3

Received 30 October 2019

Revised 22 April 2020

11 June 2020

Accepted 6 July 2020

\title{
Methods in assessing the values of architecture in residential neighbourhoods
}

\author{
Lidwine Spoormans and Ana Pereira Roders \\ Faculty of Architecture and the Built Environment, Delft University of Technology, \\ Delft, Netherlands
}

\begin{abstract}
Purpose - Although residential neighbourhoods are the largest and most resilient share of a city and the process of urban conservation and renewal is ongoing, methods to assess their values are limited. This paper presents the results of a systematic literature review, revealing the state of the art and its knowledge gaps with regard to methods for assessing values of architecture in residential neighbourhoods.

Design/methodology/approach - The systematic literature review is based on studies selected by a research protocol, using a digital database of peer-reviewed literature. A metanarrative approach is used to synthesise the qualitative data from reviewed articles. This review has two stages: (1) giving an overview of the field and (2) categorising research methods and disciplines.

Findings - The review revealed a wide variety of studies from different disciplines and deduced its key trends, titled as "storylines", concerning the methods to assess significance, integrating a broader scope of values and different perspectives. In particular, the "storylines" outside traditional heritage disciplines offer methods to include more stakeholders, link value assessment to policy development or highlight heritage potential. Results reveal the diversity in concepts and strengthen the need for an interdisciplinary vocabulary on values and methods, enabling planners and policymakers to compare their results and help to create more attractive and resilient cities.

Originality/value - By reviewing and comparing the selected studies from a wider range of disciplines and research fields, this paper shares insights into the complementary characteristics of the different types of value research, outlining the added value of the different perspectives.
\end{abstract}

Keywords Systematic literature review, Significance assessment, Heritage, Residential neighbourhoods, Housing, Multidisciplinary methods

Paper type Literature review

\section{Introduction}

The assessment of values in architecture and urbanism is at the core of the discipline of heritage conservation and is based on various international documents and charters published over the 20th century (ICOMOS, 1964; Council-of-Europe, 1975; ICOMOS, 1994; Australia ICOMOS, 1999; UNESCO, 2011). The need to discuss the methods for assessing values and varied range of disciplines in the heritage field was addressed already during 1998-2005 by the Getty Conservation Institute in its research titled "Research on the Values of Heritage". In its reports, the status quo is revealed to be led by heritage specialists and experts who determined what constitutes "heritage", what are its underlying values and how they should be conserved. The "right to decide" of these specialists is validated by the authorities who fund their work (De la Torre, 2002). Their methods of assessing heritage significance heavily rely on historical, art historical and archaeological notions held by

International Journal of Building Pathology and Adaptation Vol. 39 No. 3, 2021 pp. $490-506$ Emerald Publishing Limited 2398-4708

DOI 10.1108/IJBPA-10-2019-0095

(C) Lidwine Spoormans and Ana Pereira Roders. Published by Emerald Publishing Limited. This article is published under the Creative Commons Attribution (CC BY 4.0) licence. Anyone may reproduce, distribute, translate and create derivative works of this article (for both commercial and non-commercial purposes), subject to full attribution to the original publication and authors. The full terms of this licence may be seen at http://creativecommons.org/licences/by/4.0/legalcode 
professionals, and they are applied basically through disciplinary methods (Mason, 2002a). So, the field of heritage conservation was traditionally dominated by experts, mainly covering historic values and related methods. But, times are changing. The concept of what is heritage has evolved and expanded, which was the reason for the Getty Conservation Institute to explore the inclusion of other stakeholders and disciplines.

Moreover, the traditional heritage discipline usually regards listed buildings mainly wherein the value of the existing architecture and preservation is informed by experts. In the contemporary discourse, the definition of what can be heritage has been expanded. Where the emphasis used to lie on the high points of history and art, in the last decades' younger objects and commonplace buildings and neighbourhoods started being addressed by heritage studies. In "Building in the Stubborn City", Meurs (2008) discussed a paradigm shift in the heritage field: "from exceptional to perfectly ordinary". But Petzet and Heilmeyer (2012) stated that the value of ordinary buildings is usually not recognised. In their exhibition and book "Reduce Reuse Recycle", they pleaded for the discovery of the built environment, even if dilapidated, strange and ordinary, to reveal its potential as an architectural resource.

Residential buildings and neighbourhoods are seldom listed as monuments, although older neighbourhoods, e.g. historic centres are designated as heritage, when part of a conservation area. Because of the nature of housing as the domain of the individual, one can even question whether protection of residential buildings by listing is even effective. Especially for dwellings, the public interest of a protected status might even stand in the way of contemporary ways of dwelling (Spoormans, 2018). Instead of listing more architectural objects and areas as monuments, leading to a "heritage sprawl" (Meurs, 2008), the current debate in urban development advocates for new methods to assess values and promote greater tolerance for change, uncommon for older categories of heritage, e.g. monuments. Many acknowledge that the scope of values should be broadened but the methods to assess the values of architecture and urbanism are limited both in research and practice. Traditional history-based assessments of significance (also known as the heritage values) are still dominating most urban development policies, especially in subnational governance, as local and regional authorities. In the United Nations Educational, Scientific and Cultural Organization (UNESCO) World Heritage List, there are examples of wider value systems and implementations, including minorities as stakeholders, but at national or local level this is not standard (Labadi, 2007).

Amongst scholars, accordingly, there seems to be a general recognition of the importance to include more stakeholders and a wider scope of values in the process of assessing significance. Moreover, there is a clear call to define methods to assess values of ordinary architectural resources in urban environments. However, despite the wealth of practices, there is limited research today on tools and methods to assess the values of architecture and urbanism. To identify a broader scope of values and perspectives, this paper seeks to learn from new areas outside the traditional disciplines of heritage conservation. In current professional and academic practice, what methods are being explored to assess the values of architecture and urbanism? What disciplines hold alternative strategies for assessing values that can be informative or useable for heritage strategies and development? Do multidisciplinary teams provide new methods for broader assessment? What research designs hold possibilities for assessing the everyday qualities of residential areas? This paper presents a systematic literature review to reveal the state of the art and its knowledge gaps with regard to methods assessing the values of architecture in residential neighbourhoods. By giving an overview of the field and a comparison of used methods, this paper gives insights and examples from scholars'studies on practices to assess the values of architecture in residential neighbourhoods.
Methods in assessing values 


\section{IJBPA}

39,3

\section{The research method}

This paper reports on a systematic literature review, designed to synthesise the findings of several studies investigating similar questions. The review is based on the "road map" for qualitative literature review, as described by Boland et al. (2017). The goal of this review is to reveal the different types of methods to assess the values of architecture in residential neighbourhoods, comparing concepts, definitions, sources and tools. Using an inductive approach, the review aims to deduce categories from the included studies. The search protocol illustrates the process of inclusion/exclusion (Table 1).

The authors are convinced that despite limitations, e.g. the exclusion of books, other documents and studies from the pre-digital era, this review contributes to the discussion on the state of the art of academic research focussed on the values of architecture and urbanism. This sample of publications enables the comparison of various research fields, disciplines and geographical contexts that could easily be overlooked when using traditional methods of literature research like hand searching or citation chaining. But most important, the performed systematic literature review was based on a defined and transparent research protocol (Boland, 2017) and therefore invites to be repeated and extended by future research.

The review followed two stages (see Table 1). The first stage consisted of searching for the available articles on the topic, being the research question: "what are the methods for assessing the values of architecture in residential neighbourhoods?" After performing scoping searches, a bibliographic database has been searched using combinations of the following keywords: values, significance, architecture, buildings, neighbourhoods, residential, domestic and housing [1]. The database used was Scopus: an abstract and citation database of peer-reviewed literature that contains scientific journals, books and conference proceedings. This resulted in a sample of 232 articles. After the exclusion of two articles (one erratum and one editorial), 230 abstracts have been screened on the types of values that are explored in the study and the perspective from which values are assessed. Also, the 230 abstracts have been appraised on the three inclusion criteria for this review:

(1) Does the article discuss a method to explore values?

(2) Does the study focus on the values of architecture?

(3) Is the study about residential neighbourhoods?

The first stage sample was based on a formal application of search criteria, namely, the presence of words (values, significance, architecture, buildings, neighbourhoods, residential, domestic and housing) in title, keywords and abstract in the database. Then, an interpretative application of the inclusion criteria was carried out to assess all abstracts, leading to a

\begin{tabular}{lccc}
\hline Process & $\begin{array}{c}\text { Publications } \\
\#\end{array}$ & Review \\
\hline $\begin{array}{l}\text { Publications that were retrieved } \\
\text { Publications that retained after one erratum and one editorial publication }\end{array}$ & 232 & Stage 1 \\
were excluded & & 52 & \\
$\begin{array}{l}\text { Publications that retained after } 178 \text { publications not meeting inclusion } \\
\text { criteria were excluded }\end{array}$ & & & \\
$\begin{array}{l}\text { Not meeting criterion: "does the article discuss a method to explore values?" } \\
\text { Not meeting criterion: "does the study focus on values of architecture?" }\end{array}$ & 66 & & \\
Not meeting criterion: "is the study about residential neighbourhoods?" & 52 & & \\
$\begin{array}{l}\text { Publications that retained after four non-English and two duplicates were } \\
\text { excluded }\end{array}$ & & 46 & Stage 2 \\
Publications that retained after one publication was not retrieved & 45 & &
\end{tabular}

\section{excluded}

Table 1.

Article inclusion/ exclusion process 
selection of 52 articles that meet all three inclusion criteria. The second criterion, "does the study focus on the values of architecture", was most decisive in the selection, with only $31 \%$ of the articles meeting the criterion (see Table 1). After the exclusion of duplicates (articles reporting about the same study), non-English articles (with English summary only), one not obtained article, 45 full-text articles have been reviewed in stage 2 .

The review analyses the types of values explored and the perspective from which values are assessed. Furthermore, the main types of research and their research traditions and assessment methods are identified. Although all-included articles are "exploring values in neighbourhoods", they are very different in the form and content. So, the data to be extracted in this review are diverse, ranging from the authors' research disciplines, type of values explored and methods for significance assessments (quantitative or qualitative). A metanarrative approach is used to synthesise the qualitative data from the reviewed articles. This method was developed by Greenhalgh et al. (2005) "to begin to make sense of large data sets drawn from heterogeneous sources". This approach is often used to explore a topic by highlighting the contrasting or complementary ways in which researchers have studied the same or a similar topic (Boland, 2017). By mapping and comparing storylines of different qualitative research traditions, the method aims to build up a rich picture of a field of study (Greenhalgh, 2005). Related to "grounded theory", developed by Glaser and Strauss (1967), the researcher starts without preset opinions, notions or preconceived theory in mind and develops the theory evidenced from the data (Groat, 2002). Following an iterative process of reading, data collection, coding (data analysis) and "memoing" (theory building), little by little the different types of research studies are identified and the papers are classified. This method leads to the identification of seven storylines of research focussed on the values of architecture in neighbourhoods.

\section{Overview}

A holistic approach to explore values of architecture could include research fields related to architecture, such as environmental sciences, social sciences, art history, engineering, arts, economics but is normally conducted by very different types of research (Hansen, 2018). This section gives an overview of the fields of studies "exploring values of architecture in neighbourhoods".

\subsection{Disciplines}

The spread of disciplines confirms that architecture is researched by various disciplines and not by architects alone. Table 2 shows the number of articles per discipline (subject area) of the journal in which the article was published. Even though architecture-related studies are categorised by the Scopus database as "arts and humanities" or "applied sciences", research

\begin{tabular}{lr}
\hline Subject area & Articles \\
\hline Social sciences & 123 \\
Engineering & 74 \\
Environmental science & 50 \\
Arts and humanities & 27 \\
Economics, econometrics and finance & 20 \\
Medicine & 18 \\
Energy & 17 \\
Business, management and accounting & 16 \\
Earth and planetary sciences & 11 \\
Material sciences & 8 \\
Other & $<7$
\end{tabular}

Methods in assessing values 
IJBPA

39,3

494

from social sciences contributed the most to this sample, followed by engineering and environmental sciences [2]. This division could be influenced by the general number of published articles per discipline, the categorisation of the used database [3] or the importance of publishing in certain research traditions.

Most publications have been published after the year 2000 [4] and are journal articles (66.5\% article and $13.1 \%$ conference paper) complemented by few book chapters, books, etc. A total of 73 articles have been published in American journals, followed by Canada (18), the United Kingdom (15), Australia (9) and Hong Kong (9), showing the predominance of Englishspeaking countries. However, researchers from a wider variety of countries publish their articles in these journals, often co-authoring in international teams. Only three authors have contributed to three articles and 14 authors have been involved in two articles. So, the sample was confirmed as diverse in the case of authors and fields of research as expected.

\subsection{Type of values}

Values concern the "principles or standards of behaviour; one's judgement of what is important in life" or a "numerical amount denoted by an algebraic term: a magnitude, quantity or number" [5]. Results reveal and compare a range of social, economic, political, historic, aesthetical, scientific, age and ecological values (see Figure 1). The values framework, developed by Pereira Roders (2007), is applied to categorise the publications on their key values (pre-coding), reflected in their narratives and arguments. This framework was chosen due to its broad scope, related to values in the built environment, integrating theories and definitions by Mason et al. (2002b), Pereira Roders (2007) and English-Heritage (2008) amongst others. The definitions of the values framework are added as an Appendix (Tarrafa Silva, 2012).

Categorising the values explored in every study, similar patterns have been found for stage 1 ( 230 articles) and stage 2 ( 45 articles). Figure 2 (a) illustrates the 1:3 ratio between the number of studies that focus on one specific type of value and studies that explore more

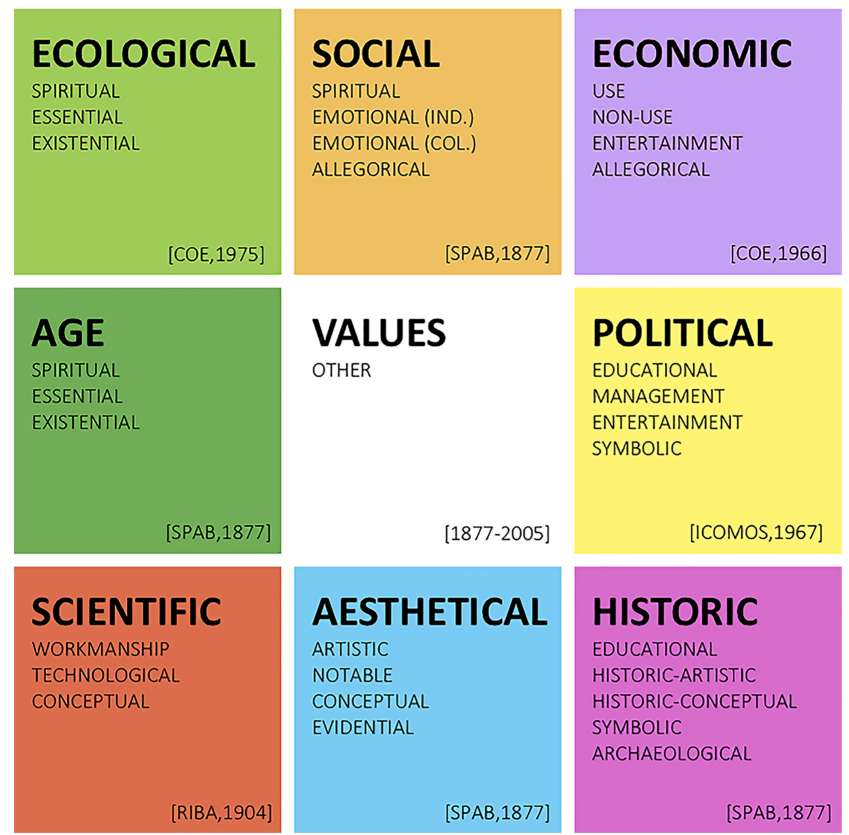

Figure 1.

The values framework by Pereira Roders (Pereira Roders, 2007) 


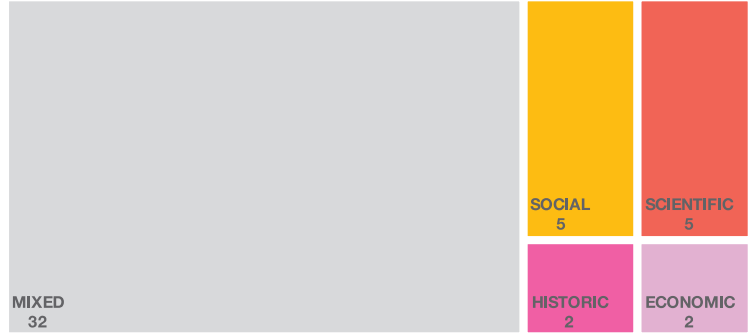

(a)
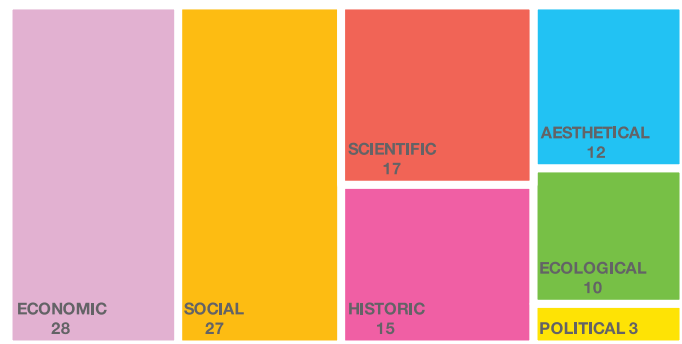

(b)
Methods in assessing values

495

Figure 2.

(a) Studies focussing on one value category, (b) Value categories explored in studies

values (mixed). Figure 2(b) illustrates the accumulated number of studies regarding a value category. Both figures show a similar spread over the value categories with the economic, social, scientific and historic values being the only values researched individually and also ranked highest in mixed values. Economic values, in the applied values framework, not only include financial value but also functionality and utility of the asset. The functional value, as a "secondary value", was approximately one-third of the articles addressing economic value (Huuhka, 2018; Song, 2012; Adair, 2014; Asan, 2018). The functionality of residential areas as a research topic is not limited to the financial-economic discipline, explaining the large share of research studies focussing on economic values. Another value in which a "secondary value" is worth mentioning is technological value, as a part of scientific value. Approximately $80 \%$ of the scientific value score represents technical topics related to the engineering discipline (e.g. Saha, 1991; Rode, 2014; Elci, 2018; Sharif, 2012) (Table 2).

The aesthetical value appeared under-represented with only one-quarter of the articles referring to aesthetics (Nordwall, 2013; De Jong, 2014; Smith, 1993; Bazzaz, 2016; Jalaludin, 2012; Riccardo, 2012; Suikkari, 2008). Moreover, the age value revealed under studied. Even though in some articles the old age of such neighbourhoods was the reason to start studying a typology or an area (Ruivo, 2017; Benkö, 2015; Zhao, 2004; Saha, 1991), the age values were not assessed in these research studies. Ecological values in the reviewed articles sometimes addressed ecological-spiritual values regarding harmony between building and environment (Bazzaz, 2016) or ecologically essential values indicating ecological ideologies in the design (Mohtat, 2018). However, in most studies, a more technical interpretation of ecology was used as the influence of building characteristics on energy performance (Braulio-Gonzalo et al., 2017; Hachem, 2012), the behaviour of residents related to energy performance (Behbehani, 2017) or the effect of energy labels on housing prices (Fuerst, 2016). 
IJBPA

39,3

496

\subsection{The perspective of the study}

When researching values, the aim to assess them should be defined. A value for whom? After all, what is valuable for one can be worthless for other. That subjective aspect of significance assessments is recognised in various reviewed studies, and academics have been developing both quantitative and qualitative methods to engage the variety of individuals within a given set (population/sample). This review distinguishes four perspectives: user/resident, owner, government and expert. These perspectives are based on the "heritage markets" as defined by Howard (2003). The perspectives of outsiders or visitors and of media were disregarded in the scope of the study as they were less relevant to residential neighbourhoods. Although few research studies do relate to visitors, for example, by studying the influence of second- and holiday-home ownership on the sense of place (De Jong, 2014), values are researched from the perspective of the local community. The group of academics is expanded to a more comprehensive group of experts, including professionals from both practice and academia, as well as real estate, engineering, history or architecture experts. As most articles report about qualitative research, the researcher is essentially the main "measurement device" in the study (Miles, 1994). As also acknowledged by Howard, people can belong to various groups, influencing their positions and motivations. If the insider, here user/resident, is also the owner, then the role and interest are decisive for classification. The definition used in the review is as follows: who determines what is a value or how valuable something is, as researched in the study.

Similar to screening values, the perspectives also show similar trends for stage 1 and stage 2. In some articles, the perspective of a stakeholder is explicitly mentioned, but the results indicate the interpretation by the authors (see Figures 3(a) and (b)). The charts show that more than $25 \%$ of the articles use more than one perspective to assess values (Suikkari, 2008; Imam, 2013; Mohtat, 2018). However, what is more notable is the high representation of the expert's perspective. Various types of experts are included in this category, like an architecture (Huuhka, 2018; Riccardo, 2012; Navas-Carrillo, 2017; Ruivo, 2017) or a real estate expert (Portnov et al., 2005; Song, 2012). Although the user/resident's perspective is not dominant as a single focus, half of the articles include the user/resident's perspective. In case of research studies with multiple perspectives, including several stakeholders, there is often one dominant "heritage market". In some studies, the user/ resident's perspective is central, represented by the majority of the interviews, but the perspective of owners, governments and experts is studied additionally (Bervoets, 2013;

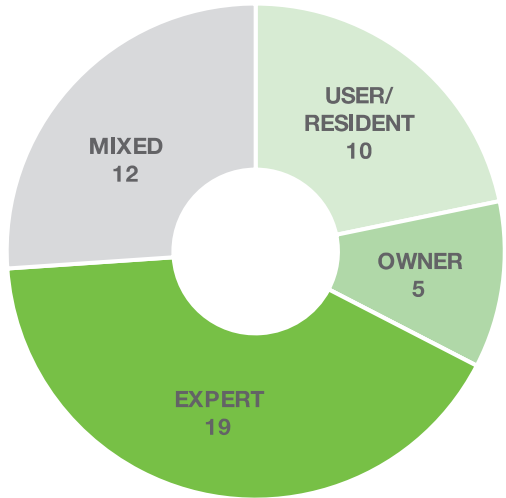

(a)

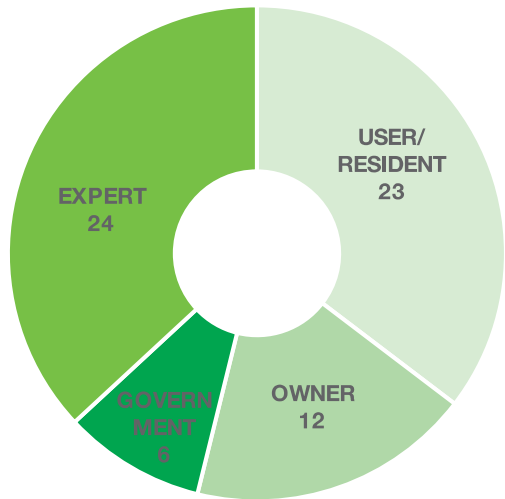

(b)
Figure 3.

(a) Studies focussing on one perspective, (b) Perspectives in the exploration of values 
Nordwall, 2013). In other research studies, different stakeholders correspond to successive stages in the value assessment, for example, starting with the resident's perspective and further selecting expert and governmental perspectives (Adair, 2014). The dominant perspective, even if more perspectives are included, is closely related to the goal of a research study, representing the interests of a "heritage market". Studies that include the governmental perspective, for example, mostly contribute to policy development, either on a national level (Bervoets, 2013; Adair, 2014) or in local communities (García, 2018; Mohtat, 2018).

\section{Research storylines}

A total of seven research storylines have been drawn, each characterised by a different combination of research methods and sources and a different focus on the values they explore and the perspective from which these are assessed (Table 3). These storylines are explained and illustrated in this section.

\subsection{Highlighting architectural legacy}

These are traditional architectural studies, researching a unique, undervalued or not widely known typology or area, such as the housing production in Porto during the postrevolutionary period (Ruivo, 2017). The main method is archival research, analysing sources such as maps, drawings and documents, sometimes complemented by photos and maps of the current situation. The research study is carried out by architects or history academics who interpret and define the expert's perspective on values. These storylines assess the historical, aesthetical and often (economic) use values. The method can be classified as interpretive historical research, often combined with elements of qualitative research, the first one studying historic and the latter studying contemporary sources. Values are defined by qualitative methods, although in many of these studies, the method is not clearly explained. The primary goal of these stories is to develop and share

\begin{tabular}{|c|c|c|c|c|c|c|}
\hline Storyline & $\begin{array}{l}\text { Main } \\
\text { discipline }\end{array}$ & Method & $\begin{array}{l}\text { Perspective } \\
\text { of study }\end{array}$ & Main data source & Key values & $\begin{array}{l}\text { Method of } \\
\text { assessment }\end{array}$ \\
\hline $\begin{array}{l}\text { (1) Highlighting } \\
\text { architectural } \\
\text { legacy }\end{array}$ & Architecture & $\begin{array}{l}\text { Interpretive } \\
\text { historical research }\end{array}$ & Expert & $\begin{array}{l}\text { Drawings and } \\
\text { documents }\end{array}$ & $\begin{array}{l}\text { Historical/ } \\
\text { aesthetical }\end{array}$ & Qualitative \\
\hline (2) The integral view & Architecture & Mixed method & $\begin{array}{l}\text { User/ } \\
\text { resident }\end{array}$ & $\begin{array}{l}\text { Multisource: } \\
\text { documents, } \\
\text { testimonies, } \\
\text { observations, etc. }\end{array}$ & Mixed & $\begin{array}{l}\text { Qualitative } \\
\text { (combination } \\
\text { quantitative) }\end{array}$ \\
\hline $\begin{array}{l}\text { (3) How to improve } \\
\text { the world? }\end{array}$ & Engineering & $\begin{array}{l}\text { Simulation/ } \\
\text { measuring }\end{array}$ & Expert & $\begin{array}{l}\text { Objective data/ } \\
\text { measurements }\end{array}$ & $\begin{array}{l}\text { Scientific/ } \\
\text { ecological }\end{array}$ & Quantitative \\
\hline $\begin{array}{l}\text { (4) What do people } \\
\text { pay for? }\end{array}$ & $\begin{array}{l}\text { Economic } \\
\text { sciences }\end{array}$ & Hedonic price model & Owner & Property price & $\begin{array}{l}\text { Economic } \\
+ \text { other } \\
\text { value }\end{array}$ & Quantitative \\
\hline $\begin{array}{l}\text { (5) Opinions, } \\
\text { behaviour and } \\
\text { appreciation }\end{array}$ & $\begin{array}{l}\text { Social } \\
\text { sciences }\end{array}$ & Narrative method & $\begin{array}{l}\text { User/ } \\
\text { resident }\end{array}$ & Testimonies & Social & $\begin{array}{l}\text { Qualitative } \\
\text { and/or } \\
\text { quantitative }\end{array}$ \\
\hline $\begin{array}{l}\text { (6) Housing } \\
\text { appreciation and } \\
\text { aspiration }\end{array}$ & $\begin{array}{l}\text { Social } \\
\text { sciences }\end{array}$ & Mixed method & Expert & $\begin{array}{l}\text { Multisource: } \\
\text { theory, } \\
\text { testimonies, etc. }\end{array}$ & $\begin{array}{l}\text { Social/ } \\
\text { economic }\end{array}$ & Qualitative \\
\hline $\begin{array}{l}\text { (7) The influence of } \\
\text { architecture on } \\
\text { well-being }\end{array}$ & Health & $\begin{array}{l}\text { Survey and } \\
\text { observation }\end{array}$ & Government & Self-reported data & Social & Quantitative \\
\hline
\end{tabular}

Methods in assessing values 
IJBPA

39,3

498 knowledge and to draw attention towards these built heritages (Zhao, 2004; Bazzaz, 2016). For example, the research study by Navas-Carrillo (2017) about mass housing neighbourhoods in medium-sized Andalusian cities used archival drawings and observations as sources to define values of specific neighbourhoods, in order to promote the existing city as an alternative to a model of expansive growth. Historic-artistic or historic-conceptual values are presented as reasons for revaluation, emancipation and adaptive reuse. Other articles with an alike storyline, highlight the architectural legacy, make a plea for the conservation or transformation of neighbourhoods of Budapest (Benkö, 2015) or Istanbul (Dülgeroğlu Yüksel, 2017), mass housing blocks of Finnish cities (Huuhka, 2018) and the redefinition of heritage policies to better protect such neighbourhoods (Imam, 2013).

\subsection{The integral view}

The residents' perspective is key to this second type of research. Various types of data are collected, such as historical information, demographic data and narrative information. This storyline is often supported by mixed methods, with research studies combining methods like interviews, social surveys, literature review, building surveys, etc. They confirm the trend of a greater public engagement in heritage conservation (Tanaka, 2016) and neighbourhood transformations (Benkö et al., 2018). These research studies are multidisciplinary, mixing sources and/or methods. They also explore combinations of various values and/or include a broad scope of values in research like social, aesthetic, use (economic), ecological and historical (De Jong, 2014). The significance assessments are defined by a combination of qualitative and quantitative methods (Asan, 2018; Sharif, 2012). The wider scope is a unique characteristic of this storyline. For example, Mohtat (2018) compared the sustainable values of two reconstruction neighbourhoods: one constructed by a contractor and the other by residents. Sustainability is defined by three categories of values: social (cultural factors, family structure, religion, privacy and safety), economic (livelihood and income) and environmental (site and climate). Although the resident's perspective is central, some studies, like Nordwall (2013) and Suikkari (2008) incorporate other perspectives, considering perspectives of various experts, like architects, planners and estate managers. The values found by this multiperspective approach are better identified as social (identity, neighbourliness and security), economic in terms of use (flexibility and size of rooms) and aesthetic (appearance of material and coherence). The main goal of these studies is to learn how residents relate to the architecture of their neighbourhood (Mohtat, 2018), façade renovation models (Riccardo, 2012) or to seek support for a conservation policy (Nordwall, 2013).

\subsection{How to improve the world?}

Technological values are the main focus of these articles, identified as scientific-conceptual or ecological-essential, generally carried out by engineers targeting to "improve the world" on aspects like energy performance (Blasco, 2017; Hachem, 2012; Rey, 2013; Rode, 2014) or thermal comfort (Saha, 1991; Curado, 2015). Researchers use physical characteristics or measurements of urban settings or buildings as the main source for this type of research, assessing them from an engineering expert's perspective. The experts, in this category, are usually academic researchers. Their focus is to investigate urban settings or buildings on their potential for improvement. Topics mostly are related to sustainability values, like the influence of building parameters on energy consumption or performance (Rey, 2013; Blasco, 2017; Brandli, 2007). Saha (1991), for example, studied the influence of architectural form and material of housing constructions in Old Delhi on energy demand for heating and 
cooling. Although the "values" in this storyline are often quantitative (e.g. temperature), they also represent an architectural quality (e.g. use and thermal comfort). Methods are either field measurements using buildings as data sources (Curado, 2015) or simulations (Elci, 2018). The goals of these researchers range from generating knowledge to informing the physical improvements of existing stock to developing tools to enable optimal and sustainable neighbourhoods (Braulio-Gonzalo et al., 2017).

\subsection{What do people pay for?}

The researchers in this storyline assess values in relation to the price people are willing to pay. A hedonic price model is a quantitative method which these researchers often use to identify and measure the relationship between environmental characteristics, building characteristics and financial property value. These researchers focus on the owner's perspective. The sources to identify the financial value differ per study from assessor tax data (Rickman, 2009) to transaction prices (Fuerst, 2016; Yau, 2008; Tang, 2010). The corresponding value in this storyline is financial-economic value, which is related to another value category. Researchers assess, for example, the influence of types of urban design (Ryan, 2007; Song, 2012), use or modifications (Portnov et al., 2005, 2006), energy efficiency (Fuerst, 2016), refurbishment (Yau, 2008) or heritage status (Rickman, 2009) on property price. Smith (1993), for example, researched on the relation between aesthetical and financial-economic values of 19th century row housing in Boston. The variation and background of architectural styles and attributes are identified by historical sources and building data. The financial data regard the purchase price of the houses. By a hedonic price model, this purchase price is decomposed for various characteristics of the house, including architectural attributes. By relating urban and architectural qualities to financial value, this storyline presents economic evidence for other value categories, like use-economic, aesthetical, ecological or historical, positioning them as an economic asset for urban development.

\subsection{Opinions, behaviour and appreciation}

These researchers, rooted in social sciences, investigate social topics as, for example, place attachment (Arifin, 2017) and the residents' knowledge and behaviour regarding heritage status and energy labels (Behbehani, 2017). The researchers in this storyline primarily study social values in different subcategories, like emotional-individual, emotional-collective or spiritual-cultural. For example, Al-Kodmany (1999) studied the perception of visual privacy in traditional and modern Damascus housing typologies. This storyline links behaviour and appreciation of residents to details of architectural form. The data are generally testimonies collected by interviews, using the resident's perspective. Methods in this storyline are qualitative methods, such as in-depth interviews (Behbehani, 2017) and questionnaires (Al-Kodmany, 1999). The aim of these studies can be to prove a hypothesis (Arifin, 2017), to develop and share knowledge about a specific case study (Al-Kodmany, 1999; Shelton, 2010) or to provide input for improvement programmes (García, 2018).

\subsection{Housing appreciation and aspiration}

These researchers, far less than in other storylines, study residents' housing preferences. They research people's appreciation but, contrasting to the previous storyline, the values are assessed from an expert's perspective. At first, appreciation of specific housing types or neighbourhoods is studied, then results are generalised to understand housing preferences

Methods in assessing values

(1)

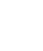


IJBPA

39,3

500

and to contribute to housing policies and developments. These research studies focus on the analysis of residents' preferences as a complex construct, influenced by various social and economic values. These researchers focus on the scale of the apartment (Al-Momani, 2000) or on a wide range of aspects and scales (Bervoets, 2013). The research study can investigate general housing preferences (Al-Momani, 2000) or a specific phenomenon like dominance of the detached single-family house in Flanders by Bervoets (2013). Their methods reveal the appreciations and aspirations of residents by either a quantitative analysis of surveys (Al-Momani, 2000) or a qualitative analysis of in-depth interviews, in combination with the literature on demographic trends and housing market mechanisms (Bervoets, 2013).

\subsection{The influence of architecture on well-being}

The influence of architectural attributes on residents' health is the focus of this storyline. These researchers investigate, for example, the impact of an urban renewal programme on the well-being of residents (Jalaludin, 2012) or the relationship between general housing condition and mental health (Adair, 2014; Green, 2013). Usually, expert observation is combined with a (self-reported) survey on health, resulting in a quantitative assessment. This storyline focusses on social values in the widest interpretation, mainly individual emotional values. The selection of attributes of influence on health is a main part of the research study, in which various experts are involved. But what sets it apart from the previous storylines is the government's perspective that is decisive on local (Jalaludin, 2012), regional (Green, 2013) and national levels (Adair, 2014). The goal in this storyline is either the evaluation of or the baseline research study on public (health or housing) policies.

\section{Discussion and conclusions}

In sum, social sciences contribute the most to research assessing the values of architecture and urbanism. Aesthetical, ecological and age values revealed under-represented, which can be indicated as a knowledge gap. When conducting research on residential buildings and neighbourhoods, social and economic values tend to be the predominant values in their assessments. The experts' view (or the academic view in Howard's terminology) remains dominant, over the residents', owners' or governments' perspectives. The review shows that different disciplines consider multiple values in their studies. This applies particularly to the studies conducting research on the integral view, a storyline that represents mixed focus, methods, sources and values.

\subsection{Lessons for methods in assessing values}

A deeper look at the distinguished storylines of values-based research provided a wide variety of methods, sources, perspectives and value categories. The researchers "highlighting architectural legacy" are close to the traditional heritage discipline, studying historical and aesthetic values from an expert's perspective. The other storylines can complement these traditional methods, enabling a more encompassing assessment of significance, as flagged need by the Getty's reports (De la Torre, 2002). First, the storylines, "the integral view" and "opinions, behaviour and appreciation" broaden the perspective towards the users. The mixed methodologies applied can provide possibilities to introduce residents as one of the stakeholder groups for assessing significance, leading to a more inclusive identification of heritage values. The methods they have applied for data collection (interviews, surveys, etc.) as well as the methods for value assessment (narrative methods, a combination of qualitative and quantitative) can enrich the present heritage practices. Second, the research studies focussing on "the influence of architecture on well-being" show how the users as a 
stakeholder group can inform policy development. Contrary to the former storylines, these researchers study the influence of the built environment on the users and not vice versa. Translated to the heritage discipline, the rigorous quantitative methods to identify attributes can provide information on the role heritage plays in people's lives. This storyline, having its base in health studies, can support heritage significance by bridging the user's perspective to policy development. Third, the storylines "how to improve the world?" and "what do people pay for?" broaden the scope of values in the heritage field. Both research approaches rely on knowledge through measurement. These research studies do not study what is the value of a heritage piece but study how heritage can be of value to face future challenges or as an economic asset. These storylines support heritage significance by including a different approach to values and focus on the potential of heritage.

\subsection{Evaluation of the methodology}

The application of a systematic literature review to this topic was challenging as it is not an established field, leading to a wide variety of publications. Due to the broad spectrum of values, the values framework, developed by Tarrafa and Pereira Roders, facilitated the classification of most values but not all. As such, this research also contributed to review definitions and relations between the values. For example, technological values are positioned as secondary values of either scientific or age value, but both categories relate to craftsmanship and skilfulness of material and techniques. The proposal is to make it distinctive, by framing the technological values to the scientific values when related to innovation, and the technological values to the age values when related to a particular period. The contemporary field of technical sustainability-led values, related to various factors, e.g. energy performance or cooling capacity, could better be subcategorised under ecological values. This framework, originally developed to identify the values of built heritage, listed and unlisted, has been proven suitable to compare multidisciplinary methods. Further research could support the further development of the framework and definitions, so that the terminology used by the different disciplines is more easily linked. Regarding stakeholders, the classification by Howard's heritage markets provided insight into the perspective for significance assessment. However, deeper research about the interest of these stakeholders involved requires additional research.

\subsection{From theory to practice}

Returning to the plea to better explore the inclusion of other stakeholders and disciplines, by the Getty Conservation Institute, we can conclude that many disciplines outside heritage conservation contribute today to the field of significance assessment, growing understanding on the values of architecture and urbanism. The storylines outside the traditional discipline of heritage conservation offer complementary ways to gain support by more inclusive perspectives, to link value assessment to policy development and/or to highlight the potential of heritage to boost the sustainability of cities and well-being of their citizens. Their methods provide help to make heritage a means to an end and not the goal of heritage conservation. Although this review focusses on the exploration of values and not on the application of values in development processes, the link to practice is, in the end, the motivation for most studies. Research to reveal the values of architecture and urbanism can inform development. The translation from ideology to practice, from policy to implementation, is a problem concerned amongst different stakeholders. Even if governmental policies express their preference for integrated approaches in neighbourhood renewal, including physical, social, economic aspects, other stakeholders like owners might have a more narrow scope (Aalbers, 2004). To get all stakeholders "on board", their interest should be included in methods to assess and deal with values. Heritage strategies and developments based on a broad scope
Methods in assessing values 
IJBPA 39,3

of values, start with methodologies to explore these in an integrative and multiperspective way. This underpins the need to continue promoting greater inclusiveness on heritage values in order to enable planners and policymakers to create more attractive and resilient cities.

\section{Notes}

1. Search result is retrieved from www.scopus.com dd. 22.11.2018, using the search formula: "values or significance and architecture or buildings and neighbourhoods and residential or domestic or housing".

2. This sample expresses the categorisation as used by Scopus, sorting architecture normally as "engineering" in their "super group" physical sciences. However, several organisations use different systems. For example, in the Dutch NWO research fields, architecture projects are "spread" over exact sciences, applied sciences, social sciences and humanities.

3. The subject area as used by Scopus is based on the subjects of the journal publishing the article, neither on the content of the article nor on the affiliation of the authors.

4. The selected period for searching articles is 1974-2018.

5. https://en.oxforddictionaries.com/definition/value Retrieved on 27.02.2019.

\section{References}

Aalbers, M., van Beckhoven, E., van Kempen, R., Musterd, S. and Ostendorf, W. (2004), Large Housing Estates in the Netherlands, Policies and Practices, RESTATE, Faculty of Geosciences, Utrecht University, Utrecht.

Adair, C.E., Kopp, B., Lavoie, J., Distasio, J., Hwang, S.W., Watson, A., Veldhuizen, S., Chislett, K., Voronka, J., Ahmad, M., Ahmed, N. and Goering, P. (2014), "Development and initial validation of the observer-rated housing quality scale (OHQS) in a multisite trial of housing first", Journal of Urban Health, Vol. 91 No. 2, pp. 242-255.

Al-Kodmany, K. (1999), "Residential visual privacy: traditional and modern architecture and urban design”, Journal of Urban Design, Vol. 4 No. 3, pp. 283-311.

Al-Momani, A.H. (2000), "Structuring information on residential building: a model of preference", Engineering Construction and Architectural Management, Vol. 7 No. 2, pp. 179-190.

Arifin, L., Widigdo, W.K., Juniwati, A. and Mintorogo, D. (2017), "The value of corridor in flat as place attachment in the life of the dwellers. AIP conference, green process, material, and energy: a sustainable solution for climate change", AIP Conference Proceedings.

Asan, H.S. and Ozsoy, A. (2018), "The importance of user memory in understanding housing quality", International Journal of Building Pathology and Adaptation, Vol. 36 No. 4, pp. 427-446.

Australia International Council on Monuments and Sites (ICOMOS) (1999), The Burra Charter, the Australia ICOMOS Charter for Places of Cultural Significance, Australia ICOMOS, Burwood.

Bazzaz, V.N. and Doostmohammadi, M. (2016), "Evolution in the correlation of iranian introverted residential architecture with the surroundings environment”, Social Sciences (Pakistan), Vol. 11 No. 18, pp. 4489-4494.

Behbehani, L.J. and Prokopy, L.S. (2017), "The appropriation of built heritage and pro-environmental behaviours: a case study of Leed certified low-income multifamily housing", Archnet-IJAR, Vol. 11 No. 1, pp. 67-82.

Benkő, M. (2015), "Budapest's large prefab housing estates: urban values of yesterday, today and tomorrow", Hungarian Studies, Vol. 29 Nos 1-2, pp. 21-36.

Benkő, M., Balla, R.B. and Hory, G. (2018), "Participatory place-making in the renewal of postCommunist large prefabricated housing estate: Ujpalota case study, Budapest", Journal of Place Management and Development, Vol. 11 No. 2, pp. 223-241. 
Bervoets, W. and Heynen, H. (2013), "The obduracy of the detached single family house in Flanders", International Journal of Housing Policy, Vol. 13 No. 4, pp. 358-380.

Blasco, L.I. (2017), "Thermal energy refurbishment of envelope in mass neighbourhood housing, located in semi-arid climate of Argentina", Sustainable Development and Renovation in Architecture, Urbanism and Engineering, Springer International Publishing, pp. 351-362.

Boland, A.M.G.C. and Dickson, R. (2017), Doing a Systematic Review. A Student's Guide, SAGE Publications Ltd, London.

Brandli, L., Kohler, R. and Frandoloso, M.A.L. (2007), "Sustainability indicators for the housing market: proposals and applications", WIT Transactions on Ecology and the Environment, Vol. 108, pp. 165-172.

Braulio-Gonzalo, M., Ruá Aguilar, M.J. and Bovea Edo, M.D. (2017), "Analysis of the influence of variables linked to the building and its urban context on the passive energy performance of residential stocks", Sustainable Development and Renovation in Architecture, Urbanism and Engineering, Springer International Publishing, pp. 15-25.

Council-of-Europe (1975), European Charter of the Architectural Heritage, Council of Europe, Strasbourg.

Curado, A., De Freitas, V.P. and Ramos, N.M.M. (2015), "Variability assessment of thermal comfort in a retrofitted social housing neighborhood based on 'in situ' measurements", , 6th International Building Physics Conference, IBPC 2015, 2015, Energy Procedia, pp. 2790-2795.

De Jong, U., Fuller, R. and Gray, F. (2014), "From fibro shacks to McMansions: considering the impact of housing change on the sense of place in the historic Victorian coastal towns of Sorrento and Queenscliff", 7th Australasian Housing Researchers' Conference, AHRC 2013: Refereed Proceedings, 2014 Fremantle, Western Australia.

De la Torre, M. and Mason, R. (2002), "Introduction", in Torre, M.D.L. (Ed.), Assessing the Values of Cultural Heritage, The Getty Conservation Institute, Los Angeles.

Dülgeroğlu Yüksel, Y. (2017), "Architecture of the city in the post-urban transformation", A/Z ITU Journal of the Faculty of Architecture, Vol. 14 No. 2, pp. 69-79.

Elci, M., Manrique Delgado, B., Henning, H.-M., Henze, G.P. and Herkel, S. (2018), “Aggregation of residential buildings for thermal building simulations on an urban district scale", Sustainable Cities and Society, Vol. 39, pp. 537-547.

English-Heritage (2008), Conservation Principles: Policies and Guidelines, English Heritage, London.

Fuerst, F., Oikarinen, E. and Harjunen, O. (2016), "Green signalling effects in the market for energyefficient residential buildings", Applied Energy, Vol. 180, pp. 560-571.

García, I. (2018), "Community participation as a tool for conservation planning and historic preservation: the case of 'Community as A Campus' (CAAC)", Journal of Housing and the Built Environment, Vol. 33, pp. 519-537.

Glaser, B. and Strauss, A. (1967), The Discovery of Grounded Theory, Strategies for Qualitative Research, Aldine Publishing Company, New Brunswick.

Green, R.D., Kouassi, M., Venkatachalam, P. and Daniel, J. (2013), "The impact of housing stressors on the mental health of a low-income african-American population", The Review of Black Political Economy, Vol. 40 No. 1, pp. 53-100.

Greenhalgh, T., Robert, G., Macfarlane, F., Bate, P., Kyriakidou, O. and Peacock, R. (2005), "Storylines of research in diffusion of innovation: a meta-narrative approach to systematic review", Social Science and Medicine, Vol. 61, pp. 417-430.

Groat, L. and Wang, D. (2002), Architectural Research Methods, Wiley, New York.

Hachem, C., Athienitis, A. and Fazio, P. (2012), "Design methodology of solar neighborhoods”, Energy Procedia, Vol. 30, pp. 1284-1293.

Hansen, B. (2018), Architectural Thinking in Practice. A Qualitative Study of Architectural Practice Seen from the View Point of a Reflective Practitioner, Delft Technical University, Delft.

Methods in assessing values 
IJBPA 39,3

\section{4}

Howard, P. (2003), Heritage - Management, Interpretation, Identity, London, Continuum.

Huuhka, S. and Saarimaa, S. (2018), "Adaptability of mass housing: size modification of flats as a response to segregation", International Journal of Building Pathology and Adaptation, Vol. 36 No. 4, pp. 408-426.

International Council on Monuments and Sites (ICOMOS) (1964), The Venice Charter, International Charter for the Conservation and Restorations of Monuments and Sites, ICOMOS, Venice.

International Council on Monuments and Sites (ICOMOS) (1994), The Nara Document on Authenticity, in Lemaire, R. and Stovel, H. (Eds), ICOMOS, Nara.

Imam, S. (2013), "Assessment and review of infill designs' guidelines for residential urban conservation areas", International Journal for Housing Science and its Applications, Vol. 37 No. 3, pp. 137-149.

Jalaludin, B., Maxwell, M., Saddik, B., Lobb, E., Byun, R., Gutierrez, R. and Paszek, J. (2012), “A preand-post study of an urban renewal program in a socially disadvantaged neighbourhood in Sydney, Australia”, BMC Public Health, Vol. 12 No. 1, pp. 1-9.

Labadi, S. (2007), "Representations of the nation and cultural diversity in discourses on World Heritage", Journal of Social Archaeology, Vol. 7, pp. 147-170.

Mason, R. (2002a), "Assessing values in conservation planning: methodological issues and choices", in Torre, M.D.L. (Ed.), Assessing the Values of Cultural Heritage, The Getty Conservation Institute, Los Angeles.

Mason, R., Low, S., Mouratano, S., Mazzanti, M., Satterfield, T. and Throsby, D. (2002b), “Assessing the values of cultural heritage", in Torre, M.D.L. (Ed.), Assessing the Values of Cultural Heritage, The Getty Institute, Los Angeles.

Meurs, P. (2008), Building in the Stubborn City, VSSD, Delft.

Miles, M. and Huberman, M. (1994), Qualitative Data Analysis, Sage Publications, Thousand Oaks, California.

Mohtat, N. and Zargar, A. (2018), "Sustainability evaluation of post-disaster housing reconstruction after 55 years: rudak village, Iran”, International Journal of Disaster Resilience in the Built Environment, Vol. 9, pp. 294-316.

Navas-Carrillo, D., Teresa Pérez-Cano, M. and Rosa-Jiménez, C. (2017), "Mass housing neighbourhoods in medium-sized andalusian cities. Between historic city centres and new peripheral developments", IOP Conference Series: Materials Science and Engineering.

Nordwall, U. and Olofsson, T. (2013), "Architectural caring. Architectural qualities from a residential property perspective", Architectural Engineering and Design Management, Vol. 9 No. 1, pp. 1-20.

Pereira Roders, A. (2007), "Re-architecture: lifespan rehabilitation of built heritage", $\mathrm{PhD}$, Technische Universiteit Eindhoven, Eindhoven.

Petzet, M. and Heilmeyer, F. (2012), Reduce Reuse Recycle, Architecture as Resource, Hatje Cantz, Ostfildern.

Portnov, B., Odish, Y. and Fleishman, L. (2005), "Factors affecting housing modifications and housing pricing: a case study of four residential neighborhoods in Haifa, Israel", Journal of Real Estate Research, Vol. 27 No. 4, p. 38.

Portnov, B.A., Fleishman, L. and Odish, Y. (2006), "Changes and modifications in residential neighborhoods as a factor of housing pricing: jerusalem and haifa as case studies", Journal of Real Estate Literature, Vol. 14 No. 3, pp. 347-380.

Rey, E., Lufkin, S., Renaud, P. and Perret, L. (2013), "The influence of centrality on the global energy consumption in Swiss neighborhoods", Energy and Buildings, Vol. 60, pp. 75-82.

Riccardo, F., van Oel, C. and de Jong, P. (2012), "Neighbourhood regeneration by facade redesign: a visual experiment on energy efficiency and aesthetics", The International Journal of Architectonic, Spatial, and Environmental Design, Vol. 6 No. 2, pp. 57-80. 
Rickman, D.S. (2009), "Neighborhood historic preservation status and housing values in Oklahoma County, Oklahoma”, Journal of Regional Analysis and Policy, Vol. 39 No. 2, pp. 99-106.

Rode, P., Keim, C., Robazza, G., Viejo, P. and Schofield, J. (2014), "Cities and energy: urban morphology and residential heat-energy demand", Environment and Planning B: Planning and Design, Vol. 41 No. 1, pp. 138-162.

Ruivo, C. and Varoudis, T. (2017), "Rethinking domestic and neighbourhood space: an analysis of social housing in the Portuguese post-revolutionary period", 11th International Space Syntax Symposium, SSS 2017.

Ryan, B.D. and Weber, R. (2007), "Valuing new development in distressed urban neighborhoods: does design matter?", Journal of the American Planning Association, Vol. 73 No. 1, pp. 100-111.

Saha, S.K. (1991), "Built form of Shahjahanabad (Old Delhi): an evaluation from the climatic point of view”, Energy and Buildings, Vol. 16 Nos 3-4, pp. 895-906.

Sharif, S.M., Zain, M.F.M. and Surat, M. (2012), "Adaptability of traditional arab house to its environment in core tripoli, Libya”, Research Journal of Applied Sciences, Vol. 7 No. 3, pp. 137-149.

Shelton, T. and Stuth, T. (2010), "Ghost houses and Trojan horses", Journal of Architectural Education, Vol. 64 No. 1, pp. 34-45.

Smith, M.S. and Moorhouse, J.C. (1993), "Architecture and the housing market: nineteenth century row housing in Boston's south end”, Journal of the Society of Architectural Historians, Vol. 52 No. 2, pp. 159-178.

Song, Y. and Stevens, M. (2012), The Economics of New Urbanism and Smart Growth: Comparing Price Gains and Costs between New Urbanist and Conventional Developments, Oxford University Press, Oxford.

Spoormans, L. (2018), Our Daily Heritage. Delft Architectural Studies on Housing From Dwelling to Dwelling, Vol. 14, pp. 54-66.

Suikkari, R., Soikkeli, A. and Reinikainen, K. (2008), "Future of Finland's reconstruction period neighbourhoods", 10th World Conference on Timber Engineering, 2008, Vol. 6, pp. 485-492.

Tanaka, Y. and Kanki, K. (2016), "Interview and community participation event about the area history for finding attractiveness of south town in Prague", in ENGINEERING, P. (Ed.), , WMCAUS2016, pp. 213-220.

Tang, B. and Yiu, C.Y. (2010), "Space and scale: a study of development intensity and housing price in Hong Kong", Landscape and Urban Planning, Vol. 96 No. 3, pp. 172-182.

Tarrafa Silva, A. and Pereira Roders, A. (2012), "Cultural heritage management and heritage (impact) assessments", Joint CIB W070, W092 and TG72 International Conference, Cape Town.

UNESCO (2011), Recommendation on the Historic Urban Landscape, in Bogyay, K. and Bokova, I. (Eds), United Nations Educational, Scientific and Cultural Organization, Paris.

Yau, Y., Wing Chau, K., Chi Wing ho, D. and Kei Wong, S. (2008), "An empirical study on the positive externality of building refurbishment", International Journal of Housing Markets and Analysis, Vol. 1 No. 1, pp. 19-32.

Zhao, C. (2004), "From shikumen to new-style: a rereading of lilong housing in modern Shanghai", Journal of Architecture, Vol. 9 No. 1, pp. 49-76.

\section{Corresponding author}

Lidwine Spoormans can be contacted at: 1.g.k.spoormans@tudelft.nl
Methods in assessing values 


\section{IJBPA}

Appendix

39,3

506

-

Table A1.

Primary

The values framework by Tarrafa and PereiraRoders (2012)

\begin{tabular}{|c|c|c|c|}
\hline & & Secondary values & References \\
\hline & & Spiritual & $\begin{array}{l}\text { Beliefs, myths, religions (organised or not), legends, stories and } \\
\text { testimonies of past generations }\end{array}$ \\
\hline & & $\begin{array}{l}\text { Emotional and } \\
\text { individual }\end{array}$ & Memory and personal life experiences \\
\hline & \multirow[t]{2}{*}{ Social } & $\begin{array}{l}\text { Emotional and } \\
\text { collective }\end{array}$ & $\begin{array}{l}\text { Notions related with cultural identity, motivation and pride, sense of } \\
\text { "place attachment" and communal value }\end{array}$ \\
\hline & & Allegorical & Objects/places representative of some social hierarchy/status \\
\hline & \multirow[t]{5}{*}{ Economic } & Use & The function and utility of the asset, original or attributed \\
\hline & & Non-use & $\begin{array}{l}\text { The asset's expired function, which has it value on the past and should } \\
\text { be remained by its existence (of materials), option (to make some use of } \\
\text { it or not) and bequest value (for future generations) }\end{array}$ \\
\hline & & Entertainment & $\begin{array}{l}\text { The role that might be have for contemporaneous market, mainly for } \\
\text { tourism industry }\end{array}$ \\
\hline & & Allegorical & Oriented to publicising financial property \\
\hline & & Educational & $\begin{array}{l}\text { The educational role that heritage assets may play, using it for political } \\
\text { targets (e.g. birth nations' myths, glorification of political leaders, etc.) }\end{array}$ \\
\hline & \multirow[t]{5}{*}{ Political } & Management & Made part of strategies and policies (past or present) \\
\hline & & Entertainment & $\begin{array}{l}\text { It is part of strategies for dissemination of cultural awareness, explored } \\
\text { for political targets }\end{array}$ \\
\hline & & Symbolic & $\begin{array}{l}\text { Emblematic, power, authority and prosperous perceptions stem from } \\
\text { the heritage asset }\end{array}$ \\
\hline & & Educational & $\begin{array}{l}\text { Heritage asset as a potential to gain knowledge about the past in the } \\
\text { future through }\end{array}$ \\
\hline & & Historic-artistic & $\begin{array}{l}\text { Quality of an object to be part of a few or unique testimonies of historic } \\
\text { stylistic or artistic movements, which are now part of the history }\end{array}$ \\
\hline & \multirow[t]{3}{*}{ Historic } & Historic-conceptual & $\begin{array}{l}\text { Quality of an object to be part of a few or unique testimonies that } \\
\text { retains conceptual signs (architectural, urban planning, etc.), which are } \\
\text { now part of history }\end{array}$ \\
\hline & & Symbolic & $\begin{array}{l}\text { Fact that the object has been part/related with an important event in } \\
\text { the past }\end{array}$ \\
\hline & & Archaeological & Connected with ancient civilisations \\
\hline & \multirow[t]{4}{*}{ Aesthetical } & Artistic & Ordinal product of creativity and imagination \\
\hline & & Notable & Product of a creator, holding his/her signature \\
\hline & & Conceptual & $\begin{array}{l}\text { Integral materialisation of conceptual intentions (implying a } \\
\text { conceptual background) }\end{array}$ \\
\hline & & Evidential & $\begin{array}{l}\text { Authentic exemplar of a decade, part of the history of art or } \\
\text { architecture }\end{array}$ \\
\hline & \multirow[t]{3}{*}{ Scientific } & Workmanship & Original result of human labour and craftsmanship \\
\hline & & Technological & $\begin{array}{l}\text { Skilfulness in techniques and materials, representing an outstanding } \\
\text { quality of work }\end{array}$ \\
\hline & & Conceptual & $\begin{array}{l}\text { Integral materialisation of conceptual intentions (implying a } \\
\text { conceptual background) }\end{array}$ \\
\hline & Age & Workmanship & Craftsmanship value oriented towards the production period \\
\hline & & Maturity & Piece of memory, reflecting the passage/lives of past generations \\
\hline & & Existential & $\begin{array}{l}\text { Marks of the time passage (patina) present on the forms, components } \\
\text { and materials }\end{array}$ \\
\hline \multirow[t]{3}{*}{$\begin{array}{l}\text { Primary } \\
\text { values }\end{array}$} & \multirow[t]{3}{*}{ Ecological } & Spiritual & $\begin{array}{l}\text { Harmony between the building and its environment (natural and } \\
\text { artificial) }\end{array}$ \\
\hline & & Essential & Identification of ecological ideologies on its design and construction \\
\hline & & Existential & $\begin{array}{l}\text { Manufactured resources which can either be reused, reprocessed or } \\
\text { recycled }\end{array}$ \\
\hline
\end{tabular}

